\title{
ANALISIS DAMPAK KARAKTERISTIK EL NIÑO TERHADAP VARIASI AWAL MUSIM MENGGUNAKAN METODE PELUANG KEJADIAN BERSYARAT DI PROVINSI NUSA TENGGARA BARAT
}

\section{ANALYSIS OF EL NIÑO IMPACT TO SEASONAL ONSET VARIATION UTILISING CONDITIONAL PROBABILITY IN WEST NUSA TENGGARA}

\author{
M. Agvi Septiarno Rachman'), Amir M. Irawan' ${ }^{2)}$, dan Dzikrullah Akbar') \\ 1) Stasiun Klimatologi Kelas III Jayapura \\ Jl. Jaring Tabri, No. 69, Genyem, Papua 99361 \\ 2) 3) Program Studi Klimatologi, Sekolah Tinggi Meteorologi Klimatologi dan Geofisika \\ Jl. Perhubungan I No. 5, Pondok Betung, Bintaro, Tangerang Selatan 15211 \\ Email : septiarnoagvi@yahoo.com
}

\begin{abstract}
El Niño phenomenom which was occurred in the period 1991-2016 caused drought in some regions, including West Nusa Tenggara (NTB). The understanding of El Niño impact to seasonal onset shifting in $N T B$ is a need to reduce negative impacts of each El Niño categories in region of NTB. This study used Oceanic Nino Index (ONI) to detect El Niño phenomenom. Furthermore, this study used dasarian rainfall data from 1991 to 2016 in season zone (ZOM) of NTB to find out seasonal onset shifting, by comparing the seasonal pattern in El Niño year with the normal condition. Conditional probability method was employed for analyzing the impact of El Niño to the seasonal onset shifting. The result shows mostly, strong and moderate El Niño influence dry season to come erlier and also influences the onset of rainy seasons that were mostly delayed with the probability ranging from $50 \%-100 \%$ in almost of NTB's seasonal zone.

Keywords : seasonal onset, El Niño, conditional probability
\end{abstract}

\section{ABSTRAK}

El Niño yang terjadi pada periode 1991-2016 menyebabkan dampak kekeringan di berbagai wilayah, termasuk wilayah Nusa Tenggara Barat (NTB). Pemahaman mengenai pengaruh El Niño terhadap awal musim di NTB diharapkan dapat mengurangi dampak negatif dari El Niño yang berbeda pada setiap wilayah di NTB. Dalam penelitian ini digunakan Oceanic Nino Index (ONI) untuk mendeteksi kejadian $\mathrm{El}$ Niño dan data curah hujan dasarian periode tahun 1991-2016 dari 10 Zona Awal Musim (ZOM) NTB untuk menganalisis pergeseran awal musim. Analisis pergeseran awal musim dilakukan dengan cara membandingkan pola musim NTB pada tahun El Niño dengan kondisi rata-rata normalnya. Dalam penelitian ini digunakan metode statistik peluang kejadian bersyarat untuk menganalisis pengaruh El Niño terhadap awal musim di NTB. Hasil penelitian menunjukkan bahwa El Niño kuat dan sedang paling berpengaruh memajukan awal musim kemarau dan memundurkan awal musim hujan dengan peluang kejadian berkisar antara 50\% - 100\% pada hampir seluruh ZOM di wilayah NTB.

Kata kunci : awal musim, El Niño, peluang bersyarat

\section{PENDAHULUAN}

Iklim maupun cuaca merupakan faktor penting dalam kehidupan sehari-hari masyarakat.

Seiring perkembangan zaman, masyarakat perlu menyadari pentingnya informasi mengenai cuaca dan iklim. Cuaca merupakan kondisi yang mewakili keadaan atmosfer dalam jangka pendek pada suatu tempat tertentu. Adapun iklim merupakan rata-rata perubahan unsur-unsur cuaca dalam 
jangka panjang yang mencakup suatu tempat yang luas. Unsur iklim atau unsur cuaca terdiri atas suhu udara, intensitas radiasi surya, lama penyinaran, kecepatan dan arah angin, kelembaban udara, tekanan udara, penutupan awan, presipitasi (curah hujan), serta evapotranspirasi (Nasir, 2008).

Wilayah Indonesia terletak di sekitar garis ekuator, yang secara terus menerus mendapatkan radiasi matahari. Sebagai salah satu kawasan tropis yang unik dinamika atmosfernya menyebabkan wilayah Indonesia rentan mengalami penyimpangan atau anomali dari kondisi normal. Anomali curah hujan umumnya disebabkan oleh fenomena global.

El-Nino merupakan salah satu fenomena global yang dapat mempengaruhi cuaca dan ikim. Kejadian El Nino biasanya diikuti dengan menurunnya curah hujan dan meningkatnya suhu udara. Ketika terjadi El Nino tekanan udara di Barat Pasifik lebih tinggi dari tekanan udara di sisi Timur. Perbedaan tekanan ini mengakibatkan pelemahan angin pasat yang pada gilirannya akan berbalik berhembus ke arah Timur. Hembusan angin ini menyebabkan perpindahan kolam air hangat (warm water pool), dari posisi semula yang berada di sebelah Barat Samudera Pasifik di atas Pulau Papua bergeser ke tengah Samudera Pasifik. Perpindahan kolam air hangat ini diikuti oleh pergeseran zona konveksi yang mengakibatkan Indonesia dan kawasan di sekitar Samudera Pasifik bagian Barat akan mengalami musim kemarau, sementara kawasan Amerika dan sekitarnya akan menerima curah hujan di atas rata-rata (Ropelewski dan Halpert, 1987).

Perubahan sirkulasi atmosfer selama El Nino menyebabkan anomali pada beberapa tempat termasuk wilayah Nusa Tenggara Barat (NTB) yang memiliki distribusi air tanah yang tidak merata sehingga pada saat kemaraunya selalu diwarnai dengan krisis air. Dampak nomali yang terjadi dapat dilihat pada pergeseran awal musim baik musim hujan maupun musim kemarau dari kondisi normal rata-ratanya yang akhirnya dapat berimplikasi serius pada aspek yang turut menunjang kehidupan sehari-hari masyarakat. El Niño menyebabkan daerah yang sumber airnya terbatas akan mengalami defisit air pada saat kemarau tiba. Terjadi hari tanpa hujan berturut-turut 


\section{STATMAT}

(Jurnal Statistika dan Matematika)

sangat panjang dan memicu kekeringan yang terjadi semakin parah sehingga menyebabkan masyarakat susah mencari sumber air bersih. Oleh karena itu, pemahaman mengenai pengaruh El Niño terhadap variabilitas awal musim di Nusa Tenggara Barat diharapkan dapat mengurangi dampak negatif dari El Niño di wilayah Nusa Tenggara Barat.

\section{DATA DAN METODE}

\subsection{Data dan Lokasi}

Data yang digunakan ialah data curah hujan dasarian periode 1991-2016 dari 10 Zona Musim (ZOM), yaitu daerah yang pos hujan rata-ratanya memiliki perbedaan yang jelas antara periode musim kemarau dan musim hujan.di wilayah Nusa Tenggara Barat.

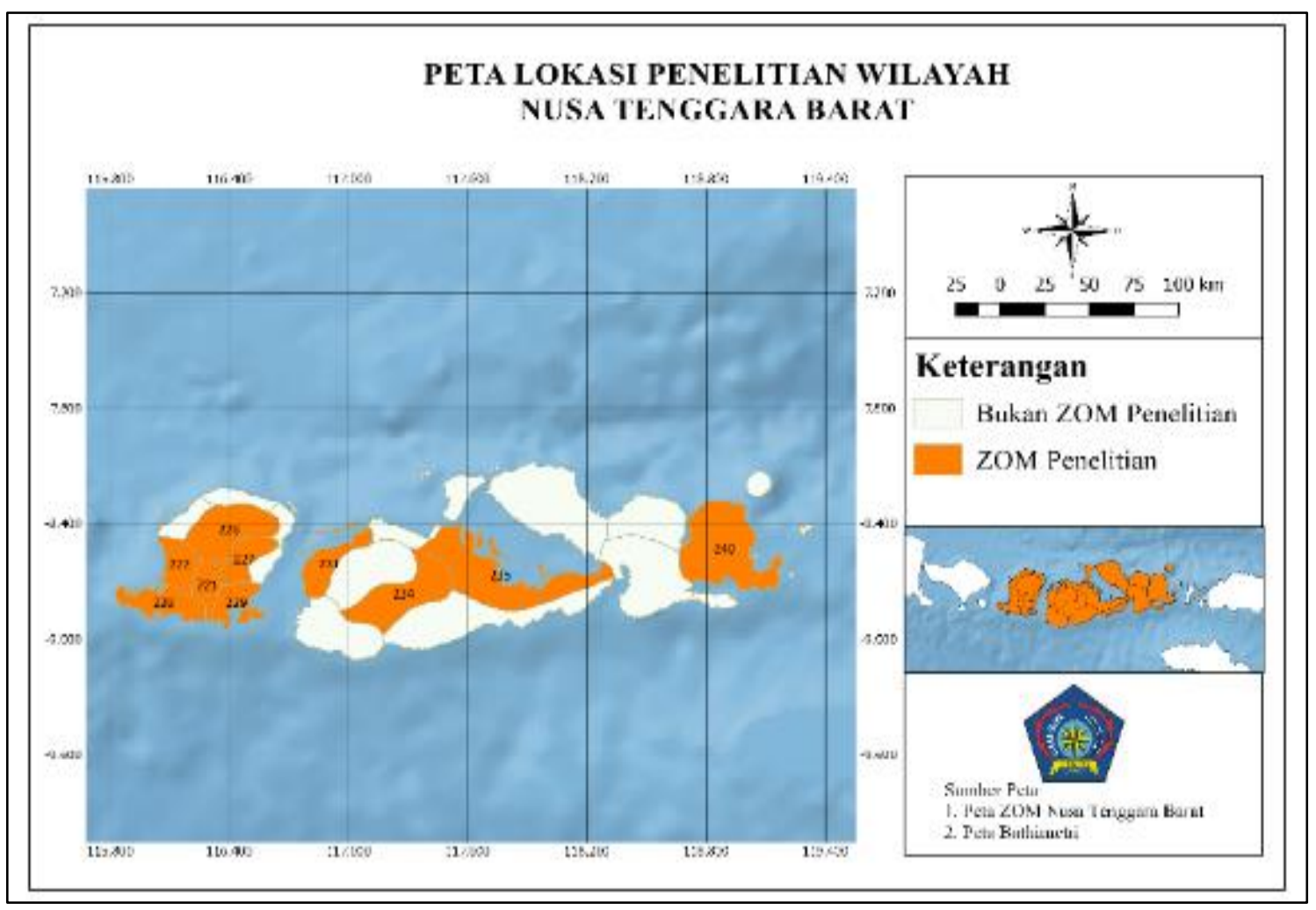

Gambar 2.1. Peta Nusa Tenggara Barat

(Sumber: http://iklim.ntb.bmkg.go.id/ dengan modifikasi) 


\section{STATMAT}

(Jurnal Statistika dan Matematika)

Data ini merupakan data observasi curah hujan dasarian yang selanjutnya dicari normal dan variasi awal musimnya. Pada penelitian ini digunakan data 10 (sepuluh) ZOM untuk mewakili penelitian di wilayah Nusa Tenggara Barat yang tersaji dalam tabel berikut.

Tabel 2.1 Data ZOM dan pos/stasiun hujan Nusa Tenggara Barat

\begin{tabular}{|l|l|}
\hline ZOM & Stasiun / Pos Pengamatan Hujan \\
\hline 220 & Sekotong, Lembar \\
\hline 221 & Puyung, Penunjak, Praya-Aikmul, Mantang, Pujut \\
\hline 222 & Peninjauan Narmada, Mataram Kediri, Mataram Majeluk, Gunung Sari, Gerung \\
\hline 226 & Batukliang, Sembalun \\
\hline 227 & Aikmel/Lenek, Mt. Gading, Kopang, Janapria, Swela \\
\hline 231 & Mujur, Sepapan \\
\hline 234 & Leteluk, Alas, Tano \\
\hline 235 & Stasiun Meteorologi Sumbawa, Moyohilir, Plampang, Lape, Empang \\
\hline 240 & Rasane, Stasiun Meteorologi Bima, Sape \\
\hline
\end{tabular}

Data tahun kejadian El Nino yang berupa data tahun-tahun kejadian El Nino kuat, sedang dan lemah dengan periode tahun 1981-2016 yang diperoleh dari http://ggweather.com/enso/oni.htm. Data ini digunakan sebagai pembanding penyimpangan awal musim. Data ONI bersumber dari pengukuran SST oleh National Oceanic and Atmospheric Administration (NOAA) pada Nino 3.4 (data anomali SST pada $5^{\circ} \mathrm{N}-5^{\circ} \mathrm{S}, 120^{\circ}-170^{\circ} \mathrm{W}$ ) dengan hasil pengukuran harian kemudian dijadikan rata-rata bulanan. Dalam penelitian ini fokus terhadap El Nino lemah, sedang dan kuat. 


\subsection{Metode Analisis}

Metode yang digunakan untuk mengetahui variabilitas musim di Nusa Tenggara Barat pada saat El Nino lemah, sedang dan kuat adalah dengan menganalisis pergeseran awal musim saat tahun El Nino lemah, sedang dan kuat terhadap normalnya kemudian dihitung peluang kejadian bersyaratnya.

\section{a) Penentuan EI Nino lemah, sedang, dan kuat}

Penentuan kategori El Nino lemah, sedang dan kuat didasarkan metode standar yang digunakan oleh NOAA untuk mengidentifikasi peristiwa El Niño (hangat) dan La Niña (dingin) di Pasifik tropis. Setiap peristiwa El Niño dengan nilai indeks yang sama atau lebih besar dari ambang batas $(0,5)$ untuk setidaknya tiga bulan berturut-turut dikategorikan sebagai peristiwa El Niño. Untuk mempertimbangkan kekuatan peristiwa El Niño dalam penelitian ini, ambang batas selanjutnya dipecah menjadi kategori yang lemah (anomali SST 0,5-0,9), sedang (anomali SST 1,0-1,4), dan kuat (anomali SST $\geq 1,5$ ) (Setiawan et al., 2017).

\section{b) Penentuan periode normal musim}

Penentuan periode normal musim dengan menggunakan curah hujan sebagaimana yang telah diatur oleh peraturan teknis dari World Meteorological Organization (WMO). Periode normal musim merupakan bagian dari normal iklim dengan menggunakan data idealnya 30 tahun, dimana metode penentuan periode normal musim dengan cara merata - ratakan curah hujan selama periode 30 tahun yang telah terjadi.

\section{c) Penentuan awal musim}

Penentuan awal musim dan panjang musim didasarkan pada kriteria Badan Meteorologi Klimatologi dan Geofisika (BMKG) dengan mengambil hanya parameter jumlah curah hujan 
dasarian sebagai pertimbangan. Awal musim hujan (AMH) dimulai saat curah hujan pada dasarian pertama lebih dari $50 \mathrm{~mm}$ diikuti dua dasarian berikut, dan awal musim kemarau (AMK) dimulai saat dasarian pertama kurang dari $50 \mathrm{~mm}$ diikuti dua dasarian berikut.

\section{d) Variabilitas awal musim}

Metode untuk analisis variabilitas musim dilakukan dengan mencari variasi awal musim kemudian dibandingkan dengan penyimpangannya terhadap periode normal (1981-2010) menggunakan kriteria BMKG dan melakukan analisis keterkaitan variabilitas musim dengan tahun kejadian El Nino lemah, sedang dan kuat.

\section{e) Analisis Peluang Kejadian Bersyarat}

Metode untuk analisis peluang kejadian digunakan untuk mencari peluang kejadian suatu nilai parameter cuaca atau iklim. Analisis peluang kejadian bersyarat digunakan untuk menghitung peluang penyimpangan awal musim terkait El Niño di Nusa Tenggara Barat. Metode Conditional Probability dihitung dengan menggunakan rumus sebagai berikut.

$$
P(A / B)=\frac{P(A \cap B)}{P(B)}
$$

Keterangan :

$P(A / B) \quad=$ Peluang kejadian A apabila B telah terjadi

$P(A \cap B)=$ peluang kejadian $\mathrm{A}$ dan $\mathrm{B}$

$P(B) \quad=$ peluang kejadian $\mathrm{B}$

\section{HASIL DAN DISKUSI}

\subsection{Periode El Nino lemah, sedang dan kuat}

Untuk mengetahui tahun kejadian El Nino lemah, sedang dan kuat, maka dianalisis terlebih dahulu indeks Oscillation Nino Index (ONI). El Nino lemah dengan indeks 0,5 - 0,9 terjadi pada 
tahun 2004/2005, 2006/2007, 2014/2015. El Nino sedang dengan indeks 1,0 - 1,4 terjadi pada tahun 1991/1992, 1994/1995, 2002/2003, 2009/2010. El Nino kuat dengan indeks >1,5 terjadi pada tahun 1997/1998, 2015/2016.

\subsection{Normal Musim Hujan dan Kemarau di Nusa Tenggara Barat}

Untuk dapat mengetahui bagaimana penyimpangan kondisi musim saat El Nino lemah, sedang dan kuat, maka dianalisis terlebih dahulu normal musimnya. Awal musim kemarau di Nusa Tenggara Barat terjadi pada rentang dasarian II bulan Maret hingga dasarian I bulan Mei dengan rata-rata panjang musim kemarau 20 dasarian. Kemudian untuk musim hujannya, awal musim hujan terjadi pada antara dasarian II bulan Oktober hingga dasarian III bulan November dengan rata-rata panjang musim hujan adalah 16 dasarian.

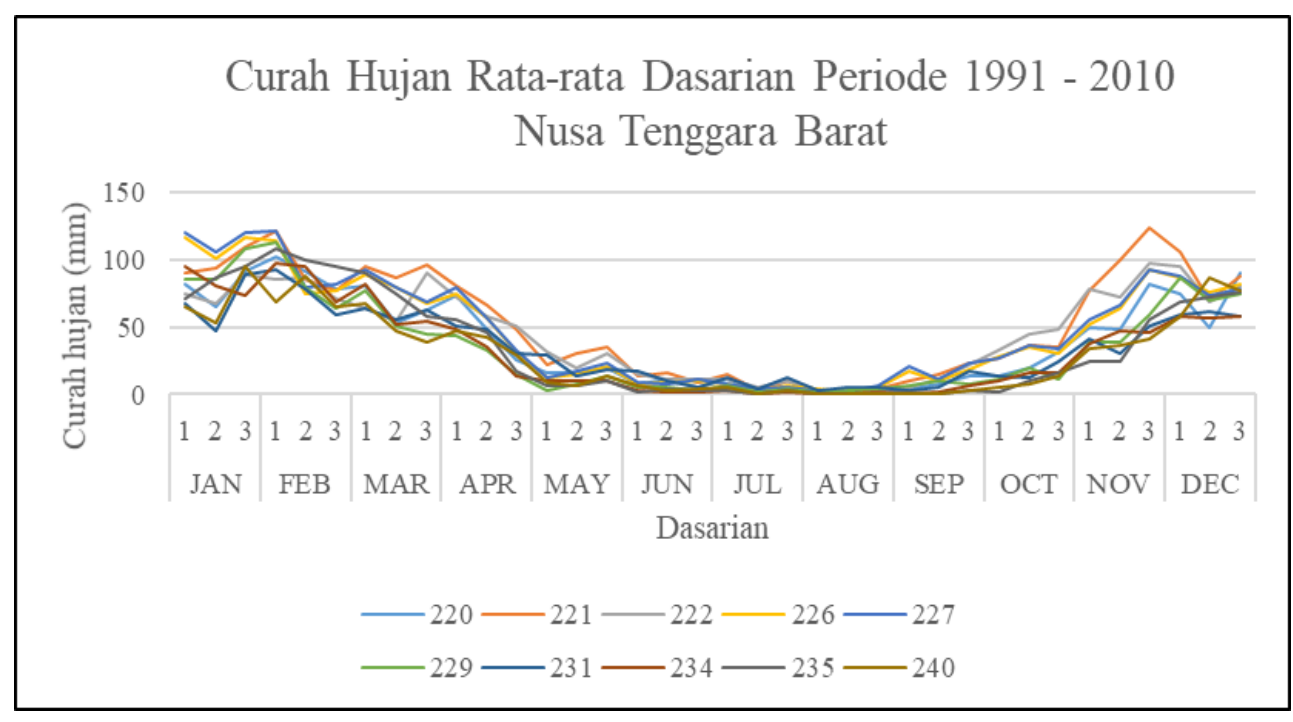

Gambar 3.1 Curah hujan normal dasarian Nusa Tenggara Barat

\subsection{Variabilitas Awal Musim Kemarau dan Musim Hujan saat EI Nino Lemah, Sedang dan Kuat}

Salah satu indikator untuk melihat variabilitas musim adalah dengan melihat maju atau mundurnya awal musimnya. Pada saat terjadi El Nino lemah (2004/2005, 2006/2007, 2014/2015), El Nino sedang (1991/1992, 1994/1995, 2002/2003, 2009/2010), El Nino kuat (1997/1998, 
(Jurnal Statistika dan Matematika)

2015/2016). Berdasarkan pengolahan pengaruh El Nino terhadap variabilitas awal musim di ZOM

Nusa Tenggara Barat (NTB) menunjukan hasil persentase pengaruh El Niño terhadap penyimpangan awal musim kemarau (AMK) dan awal musim hujan (AMH) pada tiap kategori El Niño (lemah, sedang, dan kuat) mempunyai pengaruh yang berbeda-beda di setiap ZOM wilayah NTB.

\section{a) Awal musim kemarau (AMK) lemah}

Pada saat musim kemarau terjadi pergeseran awal musim kemarau maju dari normalnya pada 4 ZOM, yaitu ZOM 221, ZOM 226, ZOM 277, dan ZOM 231 dengan persentase peluang kejadian sebesar $67 \%$ sampai dengan $100 \%$. Sebanyak 4 ZOM memiliki penyimpangan AMK mundur, yaitu ZOM 220, 229, 234, dan 240 dengan persentase $67 \%$ sampai dengan $100 \%$. Selanjutnya, terdapat ZOM 222 dan ZOM 234 yang ttidak mengalami pergeseran atau penyimpangan awal musim kemarau saat terjadi fenomena El Niño lemah. Pergeseran awal musim kemarau sangat terlihat pada ZOM 234 tahun 2004/2005 yang memajukan awal musim kemarau sebanyak 9 dasarian. 


\section{STATMAT}

(Jurnal Statistika dan Matematika)

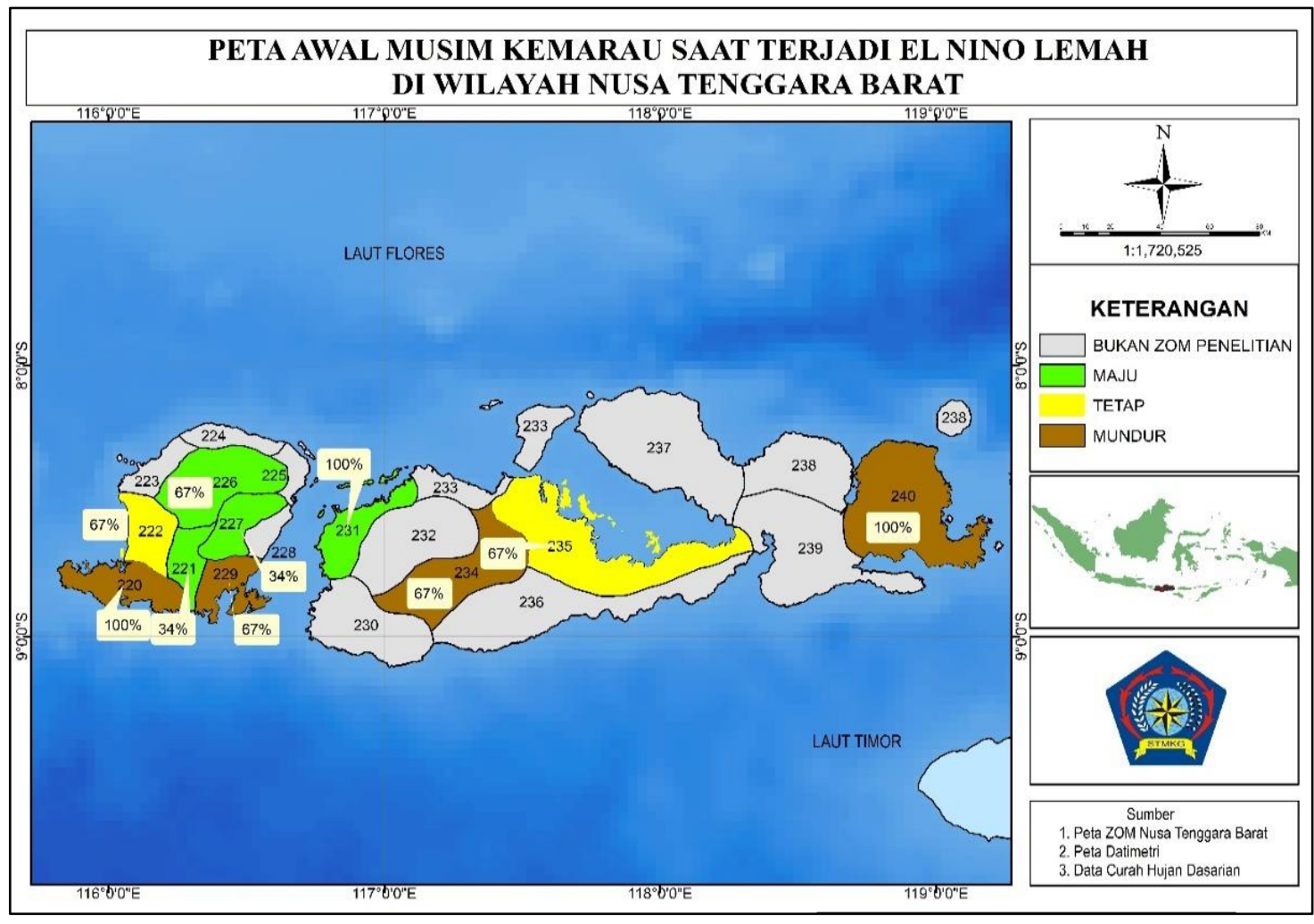

Gambar 3.1 Awal musim kemarau saat terjadi El Niño kategori lemah

\section{b) Awal musim kemarau (AMK) sedang}

Pada saat musim kemarau terdapat 8 ZOM yang memiliki penyimpangan AMK maju dari normalnya, yaitu ZOM 222, 227, 234, dan 246 dengan peluang kejadian 50\% AMK maju dari normalnya, ZOM 226 memiliki peluang 75\% maju dari normalnya, ZOM 221 memiliki peluang 90\% mundur dari normalnya, dan ZOM 231 memiliki peluang 100\% mundur dari normalnya. Hanya terdapat 1 ZOM memiliki penyimpangan AMK mundur, yaitu ZOM 229 dengan peluang 75\% serta 1 ZOM yang tetap berarti walaupun ada fenomena El Niño lemah namun awal musim kemaraunya tidak mengalami penyimpangan atau pergeseran yaitu pada ZOM 221 dengan peluang AMK tetap terhadap normalnya sebesar 50\%. Pergeseran awal musim kemarau sangat terlihat pada ZOM 222 tahun 1991/1992 yang memajukan awal musim kemarau sebanyak 12 dasarian. 


\section{STATMAT}

(Jurnal Statistika dan Matematika)

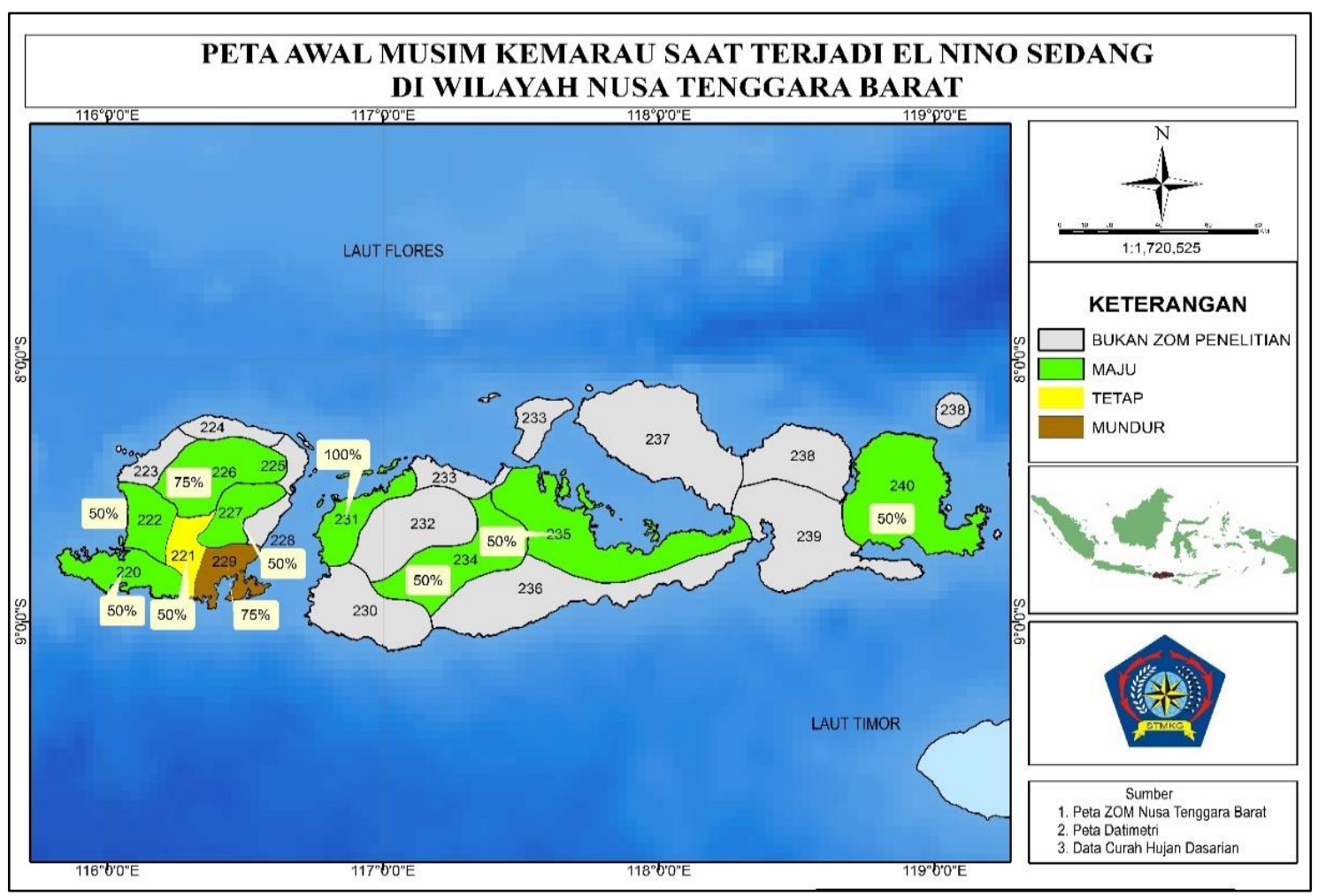

Gambar 4.6 Awal musim kemarau saat terjadi El Niño kategori sedang

\section{c) Awal musim kemarau (AMK) kuat}

Pada saat musim kemarau hampir seluruh AMK maju dari normalnya. Dari 10 ZOM penelitian, terdapat 8 ZOM yang memiliki penyimpangan AMK maju dari normalnya yaitu ZOM 226 dengan peluang 60\%, ZOM 227, 221, dan 231 mengalami peluang 100\% AMK maju dari normalnya, dan ZOM 234, 235, 240, dan 229 mengalami peluang 50\% AMK maju dari normalnya. Sebanyak 2 ZOM yang tetap berarti walaupun ada fenomena El Niño lemah namun awal musim kemaraunya tidak mengalami penyimpangan atau pergeseran yaitu pada ZOM 220 dan 222 dengan peluang kejadian AMK tetap sebesar 50\%. Pergeseran awal musim kemarau sangat terlihat pada ZOM 240 tahun 1997/1998 yang memajukan awal musim kemarau sebanyak 7 dasarian. 


\section{STATMAT}

(Jurnal Statistika dan Matematika)

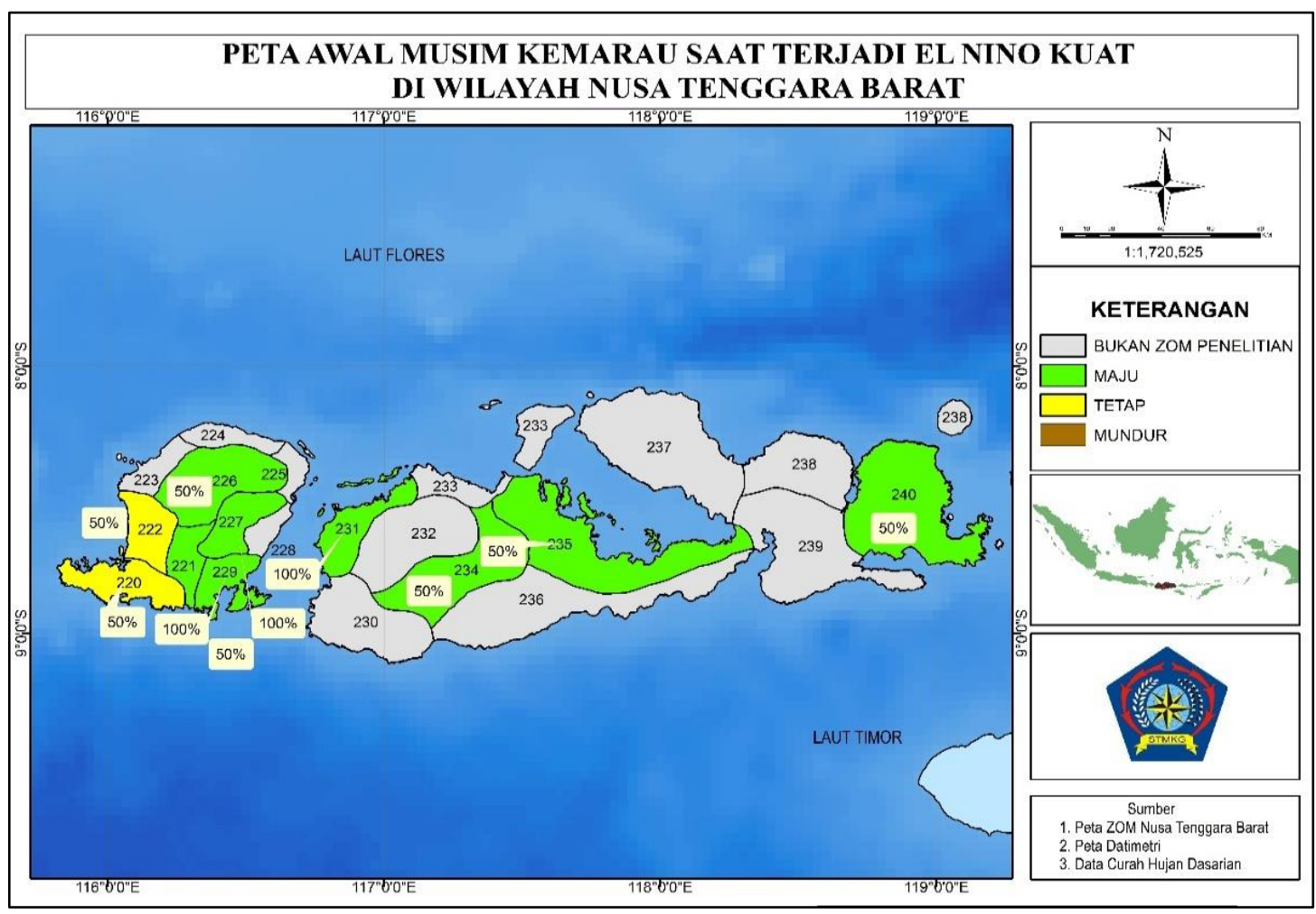

Gambar 4.8 Awal musim kemarau saat terjadi El Niño kategori kuat

\section{d) Awal musim hujan (AMH) lemah}

Pada saat musim hujan, sebanyak 5 ZOM memiliki penyimpangan AMH mundur dari normalnya yaitu pada ZOM 221, ZOM 226, ZOM 227, ZOM 231, dan ZOM 235 dengan persentase peluang kejadian sebesar 34\% - 100\%. Selanjutnya, sebanyak 5 ZOM mengalami AMH maju yaitu ZOM 220, 222, 229, 234, dan 240 dengan peluang kejadian 34\%-100\%. Tidak terdapat awal musim yang tetap berarti El Niño lemah mempengaruhi awal musim hujan. Pergeseran awal musim hujan sangat terlihat pada ZOM 234 tahun 2004/2005 yang memundurkan awal musim hujan sebanyak 6 dasarian. 


\section{STATMAT}

(Jurnal Statistika dan Matematika)

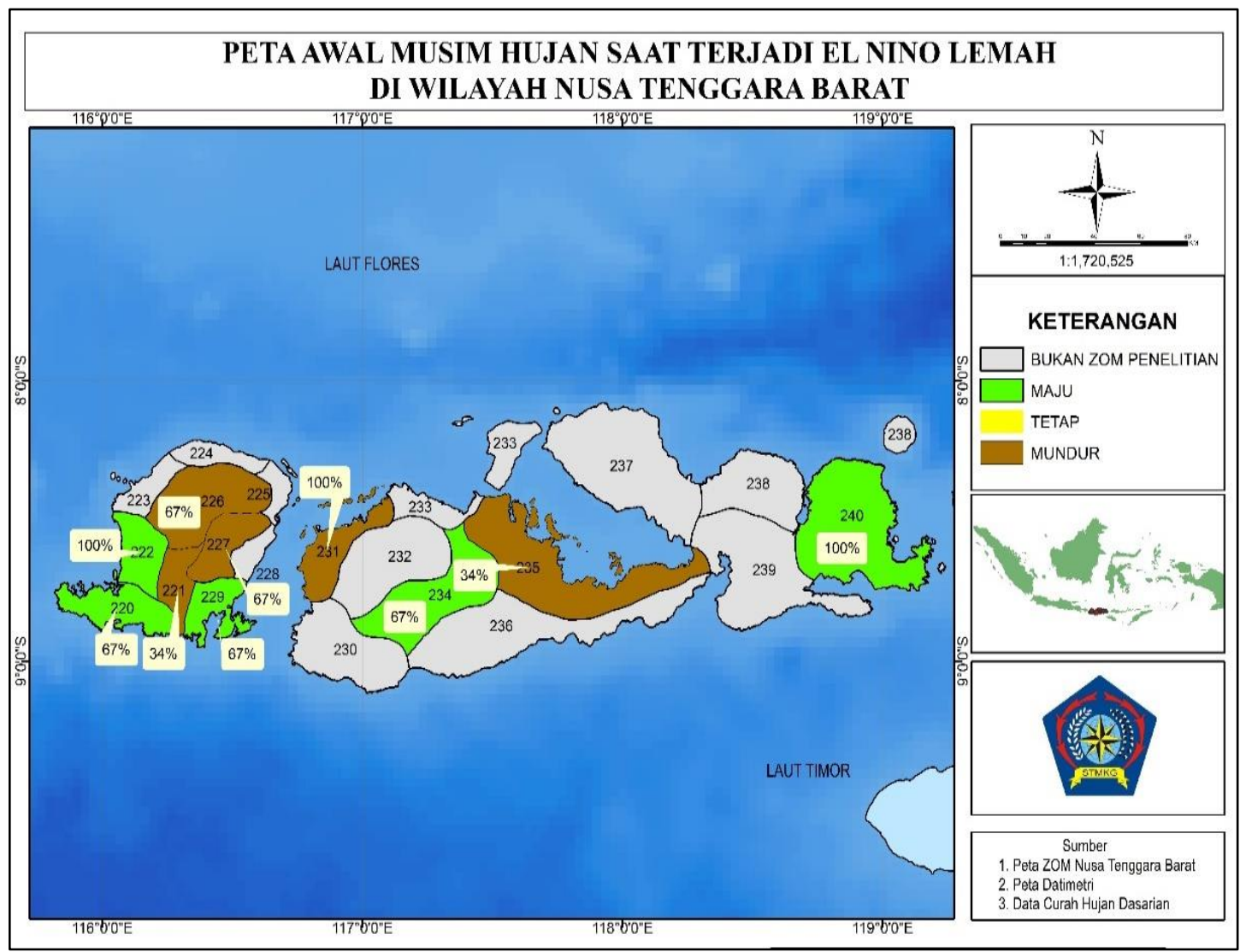

Gambar 4.5 Awal musim hujan saat terjadi El Niño kategori lemah

\section{e) Awal musim hujan (AMH) sedang}

Pada saat musim hujan didominasi ZOM memiliki penyimpangan AMH mundur dari normalnya sebanyak 6 ZOM, yaitu pada ZOM 220, 222, 226, dan 234 dengan peluang AMH mundur terhadap normalnya sebesar 50\%, serta ZOM 231 dan 235 mengalami peluang 100\% AMH mundur terhadap normalnya. Sebanyak 2 ZOM mengalami AMH maju, yaitu ZOM 221 dan 229 dengan persentase masing-masing kejadian sebesar 75\% dan 50\%. Selanjutnya, terdapat 2 ZOM dengan AMH tetap, yaitu ZOM 227 dan 240 dengan persentase 50\%. Hal ini membuktikan jika fenomena El Niño lemah tidak mempengaruhi pergeseran atau penyimpangan AMH. Pergeseran awal musim hujan sangat terlihat pada ZOM 231 tahun 1991/1992 yang memundurkan awal musim hujan sebanyak 15 dasarian. 


\section{STATMAT}

(Jurnal Statistika dan Matematika)

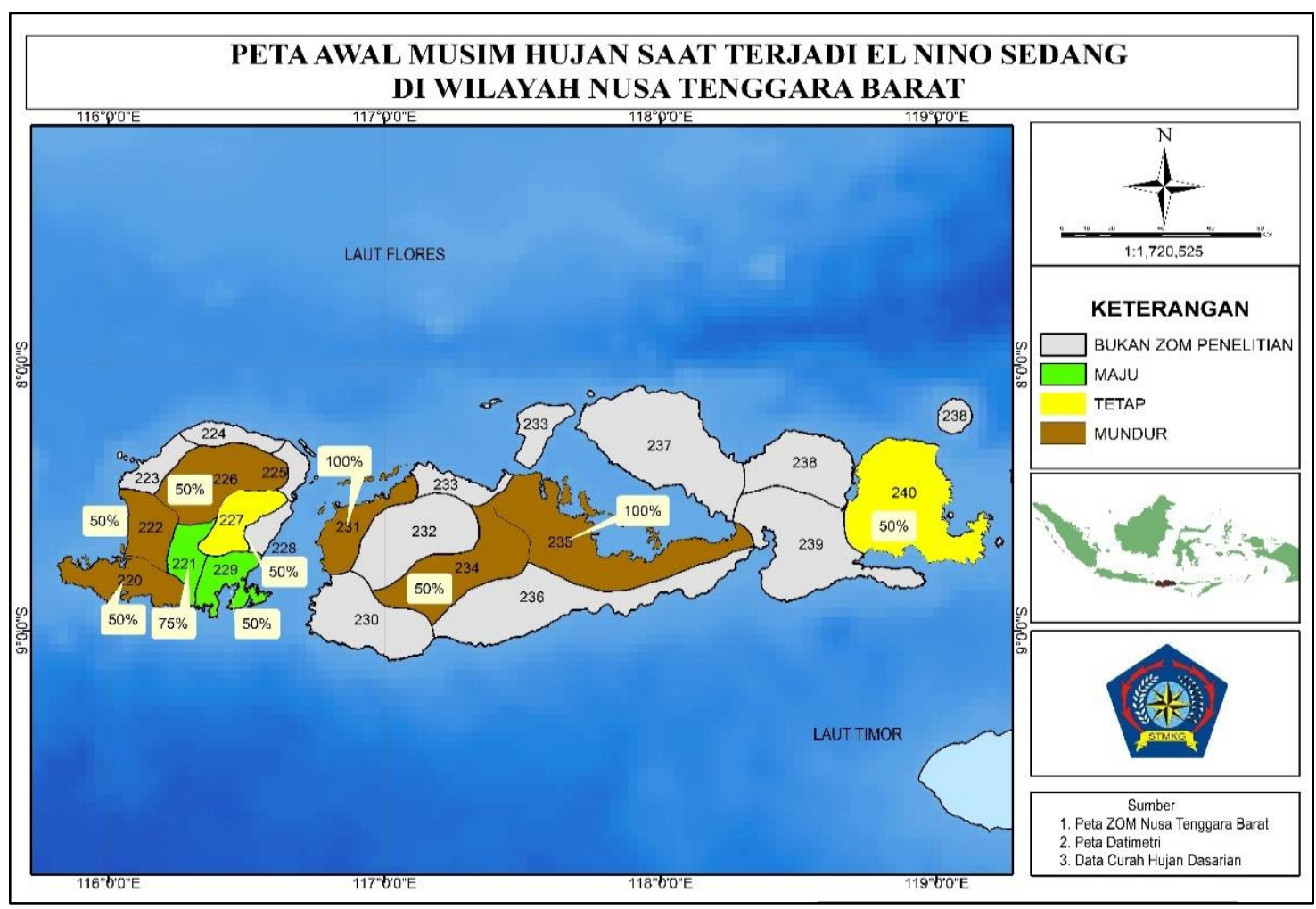

Gambar 4.7 Awal musim hujan saat terjadi El Niño kategori sedang

\section{f) Awal musim hujan (AMH) kuat}

Pada saat musim hujan didominasi ZOM yang memiliki penyimpangan AMH mundur dari normalnya. Terdapat sebanyak 9 ZOM mengalami AMH mundur dari normalnya, yaitu pada ZOM 220, 221, 226, 227, 229, 231 dengan peluang 100\%, dan ZOM 234, 235, dan 240 dengan peluang AMH mundur sebesar 50\%. Sebanyak 1 ZOM mengalami AMH maju adalah ZOM 222 dengan peluang $100 \%$ dan tidak ada ZOM yang mengalami awal musim hujan maju. Pergeseran awal musim hujan sangat terlihat pada ZOM 240 tahun 2015/2016 yang memundurkan awal musim hujan sebanyak 5 dasarian. 


\section{STATMAT}

(Jurnal Statistika dan Matematika)

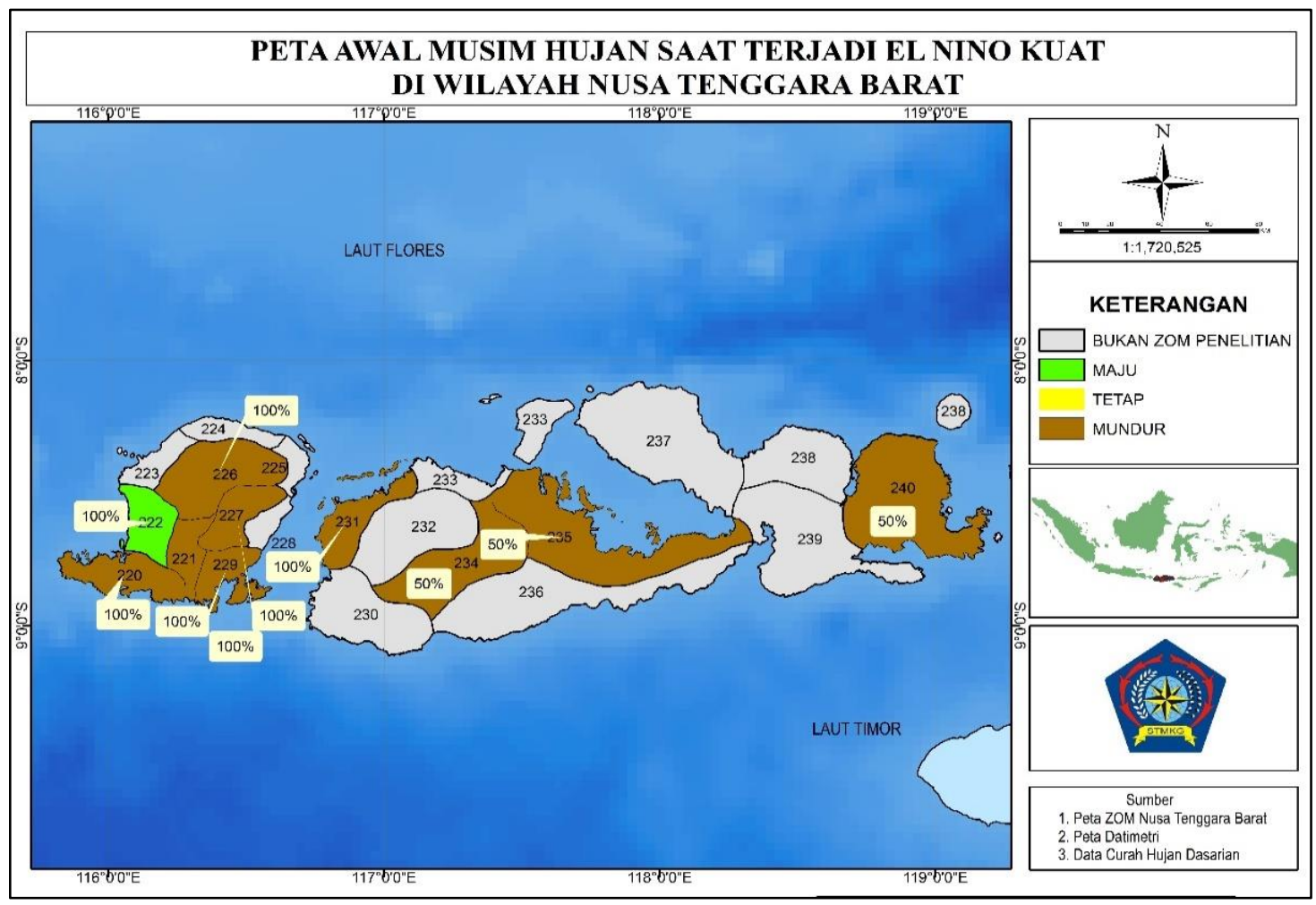

Gambar 4.9 Awal musim hujan saat terjadi El Niño kategori kuat

Dari ketiga kategori El Nino, menunjukkan bahwa El Niño kuat dan sedang paling berpengaruh memajukan awal musim kemarau dan memundurkan awal musim hujan dengan peluang kejadian berkisar antara 50\% - $100 \%$ pada hampir seluruh ZOM di wilayah NTB.

\section{KESIMPULAN}

El Niño baik kategori lemah, sedang, dan kuat memiliki pengaruh di wilayah Nusa Tenggara Barat. Pada El Nino lemah pengaruhnya masih sangat bervariasi terhadap pergeseran awal musim kemarau dan awal musim hujannya. Sedangkan pada El Nino kategori kuat dan sedang didominasi pengaruhnya dalam memajukan awal musim kemarau dan memundurkan awal musim hujan dengan peluang kejadian berkisar antara 50\% - 100\% pada hampir seluruh ZOM di wilayah NTB. 


\section{REFERENSI}

Badan Meteorologi Klimatologi dan Geofisika (BMKG) Stasiun Klimatologi Negara - Bali. 2015. Buletin Prakiraan Musim, http://www.staklimnegara.net/index.php/buletinmusim/pengertian-dan-istilah, publikasi 17 September 2015, diakses pada tanggal 9 Oktober 2018

Nasir, A. A., 2008. Modul Klimatologi Departemen Geofisika dan Meteorologi. Bogor: FMIPA IPB.

Nurdin, Hamdan. 2017. “Waspada Kondisi Cuaca-Iklim Di Periode Musim Peralihan ". Lombok Post, 9 April 2013, diakses pada tanggal 28 Desember 2018.

Ropelewski, C. F. dan M. S. Halpert. 1987. Global dan Regional Scale Precipitation Patterns Associated with the El Niño/Southern Oscillation. Monthly Weather Review 115: 16061626.

Setiawan, A.M. 2011. Penentuan Indeks ENSO Acuan untuk Wilayah Indonesia Berdasarkan Analisis Korelasi Pola Spasial dan Temporal Terhadap Standarized Precipitation Index (SPI), Tesis Program Magister, Institut Teknologi Bandung.

World Meteorological Organization (WMO). 2010. El Niño/La Niña Update, http://www.wmo.int/pages/members/members_en.html., publikasi tanggal 30 Maret 2010, diakses pada tanggal 24 Desember 2017. 